\title{
Climate change adaptation and mitigation in smallholder crop-livestock systems in sub-Saharan Africa: a call for integrated impact assessments
}

\author{
Katrien Descheemaeker ${ }^{1} \cdot$ Simon J. Oosting ${ }^{2} \cdot$ Sabine Homann-Kee Tui ${ }^{3} \cdot$ \\ Patricia Masikati $^{4} \cdot$ Gatien N. Falconnier $^{1} \cdot$ Ken E. Giller $^{1}$
}

Received: 18 April 2015/Accepted: 9 March 2016/Published online: 2 April 2016

(c) The Author(s) 2016. This article is published with open access at Springerlink.com

\begin{abstract}
African mixed crop-livestock systems are vulnerable to climate change and need to adapt in order to improve productivity and sustain people's livelihoods. These smallholder systems are characterized by high greenhouse gas emission rates, but could play a role in their mitigation. Although the impact of climate change is projected to be large, many uncertainties persist, in particular with respect to impacts on livestock and grazing components, whole-farm dynamics and heterogeneous farm populations. We summarize the current understanding on impacts and vulnerability and highlight key knowledge gaps for the separate system components and the mixed farming systems as a whole. Numerous adaptation and mitigation options exist for crop-livestock systems. We
\end{abstract}

Katrien Descheemaeker

katrien.descheemaeker@wur.nl

Simon J. Oosting

simon.oosting@wur.nl

Sabine Homann-Kee Tui

shomannkeetui@gmail.com

Patricia Masikati

pmasikatihlanguyo@gmail.com

Gatien N. Falconnier

gatien.falconnier@wur.nl

Ken E. Giller

ken.giller@wur.nl

1 Plant Production Systems, Wageningen University, PO Box 430, Wageningen, The Netherlands

2 Animal Production Systems, Wageningen University, PO Box 338, Wageningen, The Netherlands

3 International Crops Research Institute for the Semi-Arid Tropics (ICRISAT), PO Box 776, Bulawayo, Zimbabwe

4 World Agroforestry Centre (ICRAF), Lusaka, Zambia provide an overview by distinguishing risk management, diversification and sustainable intensification strategies, and by focusing on the contribution to the three pillars of climate-smart agriculture. Despite the potential solutions, smallholders face major constraints at various scales, including small farm sizes, the lack of response to the proposed measures and the multi-functionality of the livestock herd. Major institutional barriers include poor access to markets and relevant knowledge, land tenure insecurity and the common property status of most grazing resources. These limit the adoption potential and hence the potential impact on resilience and mitigation. In order to effectively inform decision-making, we therefore call for integrated, system-oriented impact assessments and a realistic consideration of the adoption constraints in smallholder systems. Building on agricultural system model development, integrated impact assessments and scenario analyses can inform the co-design and implementation of adaptation and mitigation strategies.F

Keywords Farm size - Risk - Agricultural model · Farming systems analysis · Poverty $\cdot$ Food security

\section{Introduction}

Smallholder crop-livestock systems play an important role in sub-Saharan African agriculture because of their areal extent, livelihood provision and impact on ecosystem services (Tarawali et al. 2011; Thornton and Herrero 2015). The rapidly expanding population on the continent leads to increasing food, feed and fuel demands, resulting in intense pressures on agro-ecosystems, while at the same time creating the potential for increased incomes from farming. The increasing demands for food will have to be met under 
the additional challenge of climate change, which will strongly impact agriculture. Smallholder crop-livestock systems are vulnerable to climate change and must adapt to maintain or improve productivity and its stability (Müller 2013; Thornton and Herrero 2014). Besides being vulnerable, smallholder crop-livestock systems are held responsible for large greenhouse gas emissions, but could play a role in the mitigation of these emissions (Thornton and Herrero 2010; Gerber et al. 2013).

Contrary to the strong expected impact, the actual nature and magnitude of the effects of climate change and of options for adaptation and mitigation on crop-livestock systems are not well understood. One reason for this is that most research addresses isolated system components. Without recognizing component interactions and the influence of processes at different scales, effects at the farming system scale cannot be assessed. A second reason for the lack of understanding is the bias in climate change impact and adaptation studies. Whereas climate change effects on individual crops are relatively well studied [many papers; see Müller (2013) for a summary], investigations of the effects on livestock are rare [very few papers; e.g. Thornton et al. (2009)]. Furthermore, effects on whole-farm systems are poorly studied [very few papers; e.g. Jones and Thornton (2009), Claessens et al. (2012)], and there are hardly any studies on potential impacts on future farm systems (e.g. Masikati et al. 2015). Likewise, there is a dearth of information on effects on entire farm populations that are heterogeneous in terms of resource endowments (e.g. Masikati et al. 2015). With respect to adaptation and mitigation, a wide range of options is proposed [many papers; useful reviews include Thornton and Herrero $(2010,2014)]$, but their potential effect under future climate is assessed quantitatively in few papers only (e.g. Tingem and Rivington 2009; Waha et al. 2013; Rurinda et al. 2015). The literature on adaptation potential focuses mainly on crop production with most papers investigating past trends in climate and current adaptation strategies. The constraints to adoption of climate adaptation and mitigation options are mostly discussed in general, qualitative terms (e.g. Thornton and Herrero 2014). Few impact studies take the limited adoption by smallholder farmers into account in their assessment of the adaptation and mitigation capacity, thus overestimating the potential impact [a useful exception is Thornton and Herrero (2010)]. In line with this, recent overviews (e.g. Niang et al. 2014; Lipper et al. 2014) call for a better understanding of specific barriers, as part of multi-scale and widely variable contexts, in order to inform a sustainable transformation of African farming systems (Moser and Ekstrom 2010; Rickards and Howden 2012).

In this paper, we review the above-mentioned knowledge gaps and, based on an analysis of constraints to adoption, call for whole-farm, integrated impact assessments that incorporate a realistic analysis of barriers and limits to adaptation and mitigation in African smallholder farming systems. Our objectives are to (1) summarize the projected effects of climate change, adaptation and mitigation on the biophysical components of crop-livestock systems, (2) highlight the key system characteristics and component interactions that explain vulnerability to climate change on the one hand and the typical high emission rates on the other hand, (3) provide an overview of promising options for adaptation and mitigation in mixed crop-livestock farms, (4) identify the major limits and constraints to adaptation and mitigation in smallholder crop-livestock systems, and (5) distil prospects for future research that can inform decision-making.

\section{Mixed crop-livestock farming systems and scope of this study}

Mixed crop-livestock systems integrate crop and livestock enterprises and grazing resources (pastures, rangelands) in space and time. Characteristic interactions between these components include the use of cultivated forages and crop residues as feed, the application of animal manure as organic fertilizer, land cultivation using animal draught power, economic transactions between crop and livestock enterprises, land-use conversions between rangelands and cropland and the interdependencies between animal husbandry and rangeland management. A common characteristic of mixed farming systems that is often overlooked, but typifies such systems is the multi-functionality of the herds (Mekonnen et al. 2011; Fig. 1). Livestock are kept not only for meat and milk but also for crop-supporting functions, such as traction, ploughing and manure, and functions of insurance and banking, besides cultural reasons (Moll 2005). For most of these functions, animal numbers matter more than animal productivity, which favours large herd sizes and high stocking densities (Thornton et al. 2002). African mixed farming systems are described by a large diversity in terms of land and livestock holding, soil fertility, labour availability and farmers' aspirations and attitudes (Giller et al. 2011). This diversity, combined with the large heterogeneity in the agro-ecological and socio-economic context, in which farmers are operating, complicates impact assessments and the identification of promising options for farm improvement.

In order to understand climate change impacts and the effects of adaptation and mitigation options on mixed farming systems, a systems approach is needed that takes into account the interactions between the farm components and processes at different scales. In this paper, we do this by focusing at the farm level and the biophysical factors directly impacting farm performance, while taking into 


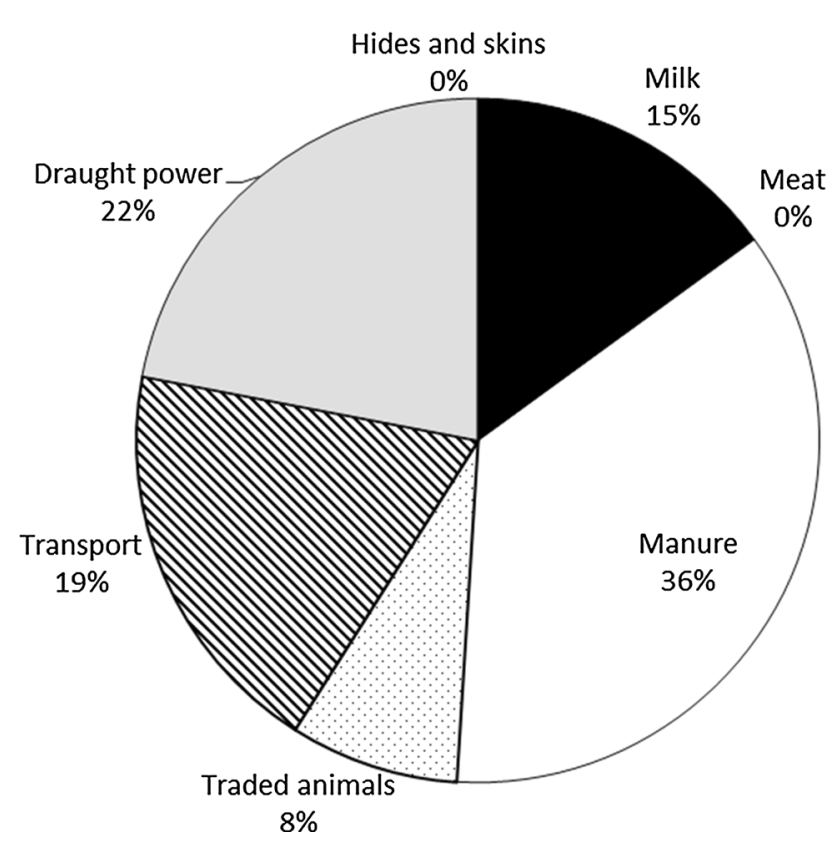

Fig. 1 Proportion of various livestock products and services to total household income, based on economic valuation and local market prices for crop-livestock systems in a sub-humid area in the Ethiopian highlands (data and methods described in Mekonnen et al. 2011)

account the contextual elements that indirectly influence farm functioning. We discuss constraints to adoption within this wider socio-economic and institutional context. We thereby recognize that climate change will alter the functioning of entire food and livelihood systems, of which farms are but one component, and that climate change is only one of several drivers of change. Indeed, the direction and magnitude of the effects on agriculture will depend on the socio-economic, policy and biophysical context (Laube et al. 2012; Müller 2013).

In this paper, we refer to several concepts. Vulnerability is the degree to which farming systems or households are adversely affected by and unable to contend with climate change. Contrastingly, resilience measures how much a system can rebound or recover from a change or a shock. Adaptation is understood as a collection of proactive and reactive actions implemented in response to current or anticipated changes in the climate.

\section{Effects of climate change on mixed crop-livestock systems}

\section{Climate change in Africa}

Climate change will be manifested through changes in climatic and atmospheric factors (rainfall, temperature and $\mathrm{CO}_{2}$ concentration), and a host of other changes and interactions. Temperatures across the African continent will rise, and it is likely that under high emission scenarios the mean annual temperature increase will exceed $2{ }^{\circ} \mathrm{C}$ by the middle of the twenty-first century (Niang et al. 2014). Changes in precipitation will be less uniform across the continent, with a varying degree of consensus between models across the regions. For southern Africa, most projections suggest a drying of the climate. For eastern Africa, however, an opposite trend is projected, with the Ethiopian highlands in particular likely to witness an increase in average and extreme rainfall. In many areas of West Africa, the changes predicted by different climate models are divergent (Niang et al. 2014). Besides trends in the mean climate, changes in weather variability and frequency of extreme events are expected, with still low but increasing confidence in the projections (Porter et al. 2014).

\section{Effects on mixed farming systems}

Climate change will impact the crop, animal and grazing resources of mixed farming systems in different ways, altering also the interactions and resource flows between them, and as such the functioning and performance of the entire system (Fig. 2). In what follows we summarize the likely effects for the major farming system components.

Climate change will affect the crop component of mixed systems through impacts on primary biomass production (grain and stover), and on crop suitability (Fig. 2). Higher temperatures accelerate plant phenology, leading to decreased yield potential (Schlenker and Lobell 2010; Sultan et al. 2013). Temperatures above or below thresholds may trigger plant senescence, and reduce leaf area growth and photosynthesis. Conversely, a shorter growing period may help to avoid drought during grain filling (Asseng et al. 2011). Furthermore, changes in temperature and rainfall affect biomass production through their effects on transpiration and water stress (Asseng et al. 2011). Crop suitability is affected by changes in the length of the growing period and changes in the frequency of crop failure as weather variability and the frequency of extreme events increase (Porter and Semenov 2005). Although the magnitude and even the direction of change vary tremendously between regions, crops and cultivars, an overall negative impact of climate change on crop yields is expected (Liu et al. 2008; Müller 2013; Niang et al. 2014). Notable exceptions to these negative projections include maize in highland areas, which may benefit from increased temperature (Thornton et al. 2010) and cassava, which, being a starch crop resistant to high temperature and low rainfall, may benefit from $\mathrm{CO}_{2}$ fertilization (Liu et al. 2008).

Direct effects of climate change on livestock production are manifested through impacts of increased temperature 


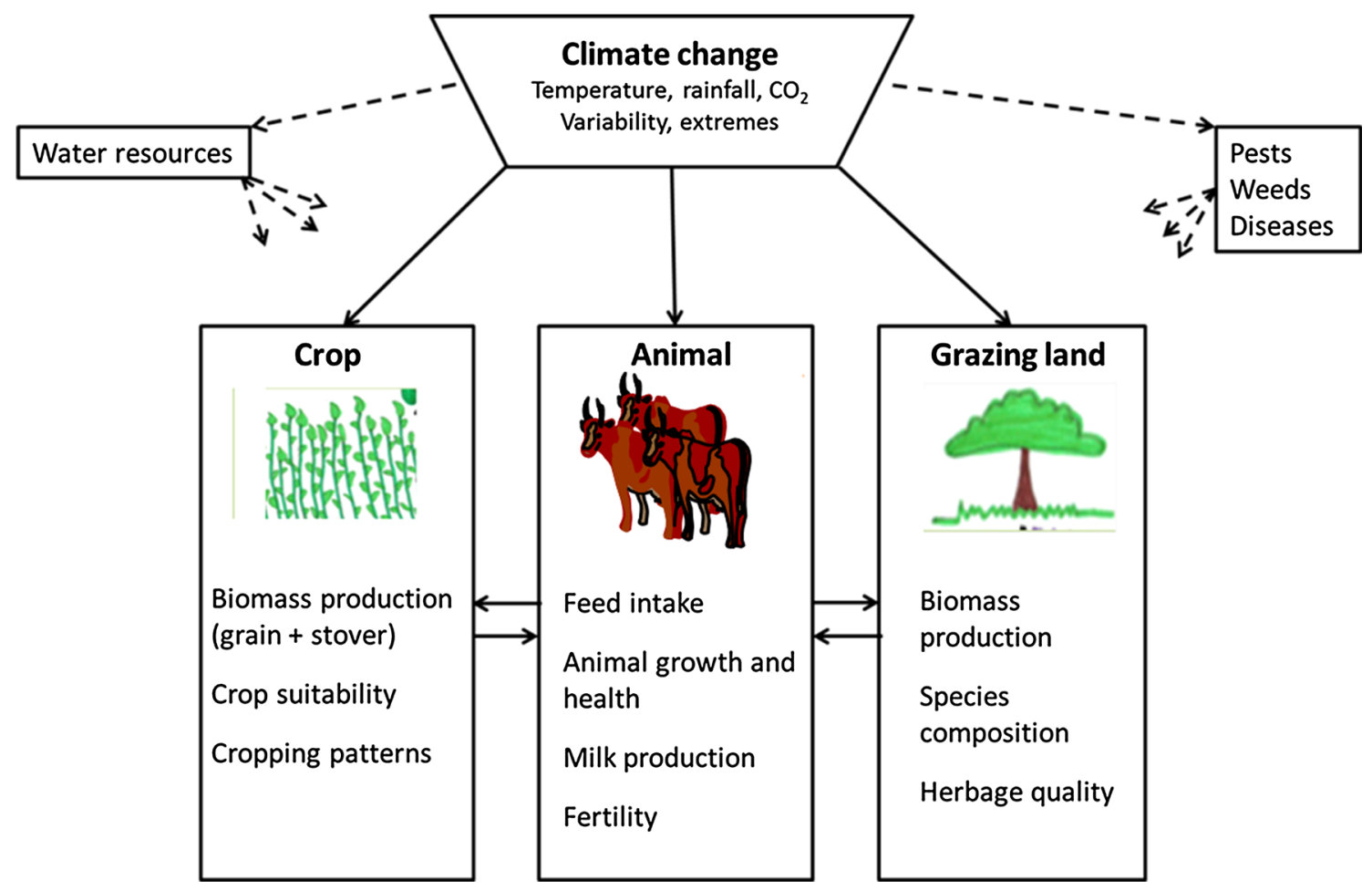

Fig. 2 Schematic representation of the effects of climate change on mixed crop-livestock systems

on feed intake and animal physiology, affecting growth, health, fertility and milk production (Fig. 2). Although the exact impact of heat stress in animals is not well established for the tropics (Thornton et al. 2009), it is likely that with increased temperatures, African livestock keepers may have to shift to more heat tolerant breeds or species. Livestock are indirectly affected by changes in forage and crop residue production and grazing resources (Thornton et al. 2009). Pastures and rangelands will be affected by climate change through changes in biomass production and species composition, which influence feed quantity and quality (Fig. 2; Thornton et al. 2009). Finally, the risk of losing entire herds increases with more frequent and prolonged droughts. This is a risk with potentially high impact, as it takes many years before livestock keepers are able to restock their herds (Toulmin 1994).

Changes in the mean climate, its distribution and the occurrence of extreme events, including heat waves, droughts and intense rainfall, will affect the availability and quality of water resources. However, predicting the actual impacts on water resources remains problematic due to the lack of observational data, the interactions with other (anthropogenic) drivers, such as land-use change, and the uncertainties in the climate signals themselves (Niang et al. 2014). Nevertheless, changes in the availability and quality of irrigation water and livestock drinking water will strongly impact crop and livestock production (Fig. 2).
Provision of drinking water for livestock is not only critical for animal survival, it also influences feed use efficiency (Descheemaeker et al. 2011).

Climate change will affect the geographic range, incidence and severity of pests, weeds and diseases, consequently impacting both crop and livestock production (Fig. 2). However, with little empirical information and existing analyses focusing mostly on single pathogens, the uncertainty around the likely effects is large (Porter et al. 2014). In particular for livestock, the increased frequency of droughts may affect the spread of livestock diseases due to livestock and wild animals congregating in smaller areas or around fewer drinking points.

Beyond effects on system components, system-level changes due to climate change are anticipated. Farming systems could shift towards a greater importance of livestock, as animals are better adapted to dry and variable climates than crops. Livestock mobility enables animals to take advantage of spatial and temporal heterogeneity in feed availability (Vetter 2005; Morton 2007). Also, livestock can still feed on crop biomass in case of grain harvest failure. Hence, trends towards more livestock-oriented systems are likely in areas where annual crops become less suitable (Jones and Thornton 2009). In extensively managed systems, seasonal migration may become more widespread. If not carefully managed and regulated, this may cause conflicts between crop farmers and livestock 
keepers (Turner et al. 2011). Along with altered crop suitability, shifts in land-use patterns and cropping systems are expected (e.g. Thornton et al. 2010). However, anticipated shifts towards small grains (millet, sorghum) at the expense of the more climate-sensitive maize are not yet witnessed. On the contrary, maize continues to expand into dry areas (Milgroom and Giller 2013; Traoré et al. 2014). Biome shifts associated with climate change (Gonzalez et al. 2010) are likely to affect grasslands and rangelands across Africa. However, due to interactions with other drivers (such as fire and grazing) and remaining uncertainty in vegetation responses, it is impossible to predict the impacts on grazing potential reliably. Generally speaking, the effects of climate change on whole-farm performance (e.g. Claessens et al. 2012; Masikati et al. 2015), as well as the likely effects on future systems, are under-researched topics (Müller 2013).

\section{Vulnerability of smallholder crop-livestock systems}

African smallholders have always had to deal with climate variability (Cooper et al. 2008; Laube et al. 2012). However, the lack of access to insurance and credit makes the majority of smallholders vulnerable to the projected increase in risk with climate change. For example, as many African smallholders are net food buyers (Jayne et al. 2006), they are vulnerable to price shocks, which may become more frequent due to increased climate variability. Furthermore, the increased frequency of extreme events is likely to reduce investments and input use and augment the proportion of low-risk subsistence activities, lowering farm productivity and profit (Porter et al. 2014; Lipper et al. 2014), as such causing an impact that may be stronger than that of changes in mean climate. Moreover, when a shock strikes, its impacts on assets, income and food security may be felt over prolonged periods, increasing the likelihood of smallholders falling into poverty traps (Dercon 2004). On the other side, modern technologies, new ways of information sharing and access to off-farm income provide options for farmers to adjust to changes in climate and the broader socio-economic context.

\section{Vulnerability related to crop production}

About $96 \%$ of African agriculture is rainfed, and irrigation infrastructure lags behind other continents (Molden 2007; FAO 2014); especially in semi-arid and sub-humid areas with high climate variability, crop production is characterized by relatively small and variable yields (Cooper et al. 2008). The dependence on rainfall results in a high sensitivity to the likely changes in amounts and distribution of rainfall associated with climate change (Morton 2007). Evidence from across Africa suggests that a later start and shortening of the growing season, and increased incidence of droughts and dry spells (e.g. Traoré et al. 2013; Rurinda et al. 2014), will negatively impact rainfed agriculture.

Besides the dependence on unreliable rainfall, poor crop yields are also explained by the poor soil fertility of many African soils (Smaling et al. 1997), resulting from weathered parent material and years of nutrient mining by agriculture. Poor soils cause an unreliable response to fertilizer application (Vanlauwe et al. 2015), and this riskiness is a disincentive for farmers to invest in agronomic inputs (Marenya and Barrett 2009). A further impediment is the lack of access to inputs (Ejeta 2010). Generally, stagnant yields (Nin-Pratt et al. 2012) and large yield gaps (van Ittersum et al. 2013) are the result. A further decrease in yields due to climate change may trigger reduced consumption or asset sales, thus increasing the probability of food insecurity and persistent poverty (Carter and Barrett 2006; Porter et al. 2014).

Increasingly, African smallholder farming systems witness a decrease in crop diversity. For example, the increasing popularity of maize in many areas of both southern (Milgroom and Giller 2013) and West Africa (Traoré et al. 2014) leads to the replacement of sorghum and millet. In southern Ethiopia, the rise in new cash crops and cereals causes a shift from multi-species homegarden systems towards systems with fewer crops (Abeba et al. 2010). These examples illustrate a trend towards systems with lower agro-biodiversity that are less able to exploit the complementarity in species' resource use and susceptibility to pests and diseases (Wood et al. 2015), thus increasing the vulnerability to change and shocks (Thornton and Herrero 2015).

With little financial capital for mechanization or herbicides, human labour is an essential resource in smallholder systems (van Vliet et al. 2015). Nonetheless, poor households often hire out their labour to earn money to buy food. This delays their own operations (e.g. planting, weeding) with poorer crop yields as a result (Kamanga et al. 2014). The ability to timely execute tactical and operational decisions is important to maintain flexible farm management, which is essential in the face of increased climate variability (Andrieu et al. 2015). Hence, labour constraints aggravate smallholders' vulnerability to changes in their environment and, in particular, to changes in climate.

\section{Vulnerability of the livestock component}

Of the many interactions between crops and animals in mixed systems, the use of crop residues as feed is of particular interest in understanding livestock's vulnerability to climate change. The proportion of crop residues in the 
animal diet may range from $<10$ to $70 \%$ in mixed systems (Valbuena et al. 2015). Crop residues are usually fed to animals to bridge the dry season, when less and low-quality feed is available for grazing. As the nutritive value of crop residues is insufficient to alleviate feed gaps and maintain animal condition, the dry season is a critical period, during which animals lose weight and become more susceptible to diseases. Logically, as climate change is expected to impact crop yields, it will have knock-on effects on animal production, which are stronger where livestock depend more on crop residues and cultivated forages.

The other important component of the livestock diet in mixed systems, grazing, contributes between 10 and $90 \%$ of the diet (Valbuena et al. 2015), depending on agroecological conditions and land pressure. In most of subSaharan Africa, grazing takes place on communal rangelands. In recent years, agreement is rising on the complexity of rangeland management, as it is influenced by biophysical, institutional and socio-economic factors (Vetter 2005). In this, herd mobility is a key strategy to exploit the spatial and temporal variations in rainfall and hence grazing resources (Morton 2007). However, ongoing settlement policies, expanding cultivated land and shifts from communal to individual tenure are impairing mobility (Vetter 2005). This not only increases the risk of degradation by concentrating grazing on smaller areas, but also increases the vulnerability of livestock keepers to changes in their grazing resources due to climate change.

\section{Greenhouse gas emissions}

The global livestock sector is responsible for an estimated $14.5-16 \%$ of global anthropogenic greenhouse gas (GHG) emissions (Gerber et al. 2013). African livestock systems are characterized by much greater emission rates per $\mathrm{kg}$ of animal product compared to other regions of the world. Gerber et al. (2013) estimated emission rates for African beef and dairy systems of 70 and $9 \mathrm{~kg} \mathrm{CO}_{2}$ equivalent per $\mathrm{kg}$ of carcass weight and fat- and protein-corrected milk (FPCM), respectively, compared to the global average of 46 and $2.8 \mathrm{~kg} \mathrm{CO}_{2}$ equivalent per $\mathrm{kg}$ of carcass weight and FPCM. In contrast, apart from regions with high stocking density, like East Africa, the emissions per unit of land are relatively small (Gerber et al. 2013; Seebauer 2014) and still smaller per unit of supported livelihood (Oosting et al. 2014).

The large emission densities in the African smallholder systems are related to the use of fodder sources with low digestibility, resulting in large enteric emissions and to poor animal husbandry and herd management, leading to high mortality, low reproductive performance and low milk and meat productivity (Gerber et al. 2013). Additional emissions of methane and $\mathrm{N}_{2} \mathrm{O}$ occur during storage, processing and application of manure (Rufino et al. 2006). Finally, changes in the carbon stock of biomass and soils due to changes in land use (e.g. expansion of cultivated land) or land management (e.g. grazing management and crop residue management) also play a role (Seebauer 2014).

\section{Adaptation and mitigation options}

Adaptation and mitigation are two of the three pillars of climate-smart agriculture (CSA), with the third pillar aimed at increasing food security through increased agricultural productivity (Campbell et al. 2014). In Fig. 3, we categorize promising options for mixed smallholder farms according to three (somewhat overlapping) strategies of risk management, diversification and sustainable intensification, and according to their focus on crops, livestock and rangelands, and the integrated farm system as a whole. Risk management typically aims to reduce the variance of an outcome (e.g. crop yield), whereas intensification primarily aims at increasing the mean of the outcome. Diversification may lead to a shift in both the variance and the mean. Figure 3 presents the logic that an adaptation and/or mitigation option is promising only if first of all the objective of increasing food security is fulfilled. Secondly, increased resilience and adaptive capacity are deemed more important for smallholders than mitigation. In other words, mitigation can be conceived as a co-benefit of increased productivity and adaptation. Figure 3 focuses on technical, crop, livestock and rangeland management options, while indicating some important institutions that could enable the adoption of these options.

\section{Adaptation options}

Many risk management and diversification strategies are not new to African households who have traditionally dealt with climate variability through, for example, (seasonal) migration, combining multiple crops and or cultivars, diversifying livestock herds, and utilizing the complementarities between crop cultivation, livestock and trees (Thornton and Herrero 2014). Farmers can adapt to shorter and more variable growing seasons by choosing drought resistant or shorter maturing crops and varieties and adjusting planting dates (Niang et al. 2014). Such agronomic management decisions can be informed by detailed crop growth modelling results, which showed, for example, for Zimbabwe that a moderate delay in planting to avoid early-season dry spells can be beneficial (Rurinda et al. 2015). Similarly, the choice for animal types and breeds that are better adapted to heat stress and dry conditions 
Fig. 3 Farm-level technical options in vertical ovals indicating the contribution to the three climate-smart agriculture objectives of (1) food security and agricultural productivity, (2) adaptation and resilience and (3) mitigation, categorized according to three strategies of (i) risk management, (ii) diversification and (iii) sustainable intensification. Colours indicate a focus on the crop component (green), the livestock and rangeland components (brown) and the whole integrated farm system (yellow). Options that would only contribute to increased productivity and food security are not shown.

Enabling institutions at the bottom are placed underneath the strategy that they underpin most. Dashed lines and arrows indicate the blurred nature of boundaries and the overlapping influence spheres (colour figure online)

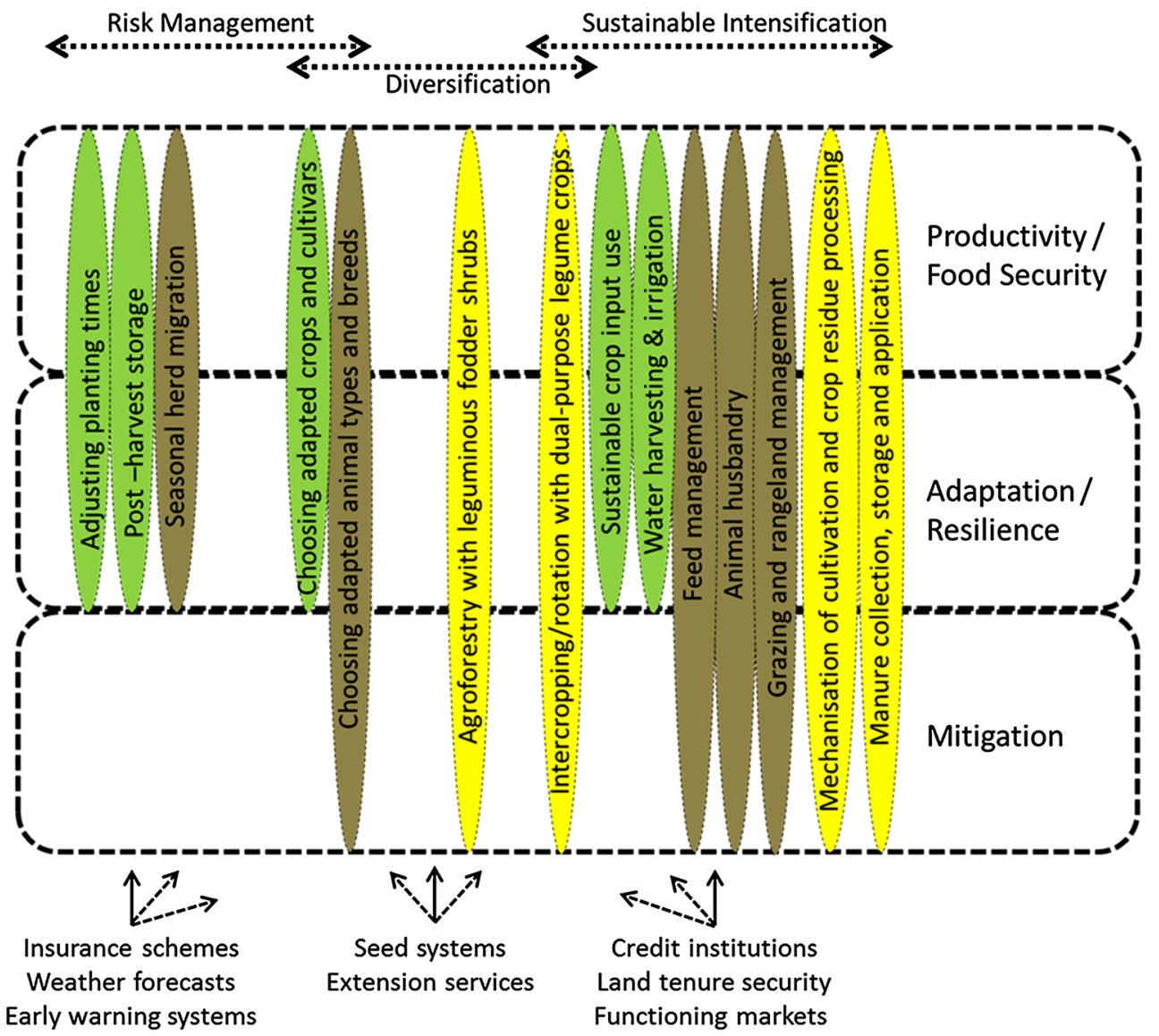

(e.g. goats instead of cattle; sturdy African breeds instead of more productive cross breeds) is a logical avenue for climate change adaptation. Also improving the storage of food and feed, including measures to fight post-harvest losses (Milgroom and Giller 2013), will help households to bridge dry seasons or years of crop failure, thus cushioning them against likely increases in climate variability.

Sustainable intensification encompasses a wide array of options for farm performance improvement that can increase the adaptive capacity of smallholder systems (Campbell et al. 2014). These options typically require investment and more complex farm management operations. Integrated soil fertility management (Vanlauwe et al. 2015) can include intercropping with dual-purpose leguminous crops, combined with judicious use of mineral and organic fertilizers, which may offset negative climate change effects on productivity at relatively low costs (Masikati et al. 2015; Rurinda et al. 2015). With projected changes in evaporative demand and rainfall amount and distribution, practices that mitigate water stress, such as water harvesting, soil and water conservation and irrigation (Laube et al. 2012), also provide important adaptation mechanisms. Further, mechanisation can help to alleviate labour shortages thus contributing to timely farm operations and farmers' agility to respond to unexpected events or changes. From the animal perspective, options that alleviate current feed gaps in the vulnerable dry season present a key strategy. Livestock diets can be improved by introducing dual-purpose crops of which the haulms or straw have relatively good feeding value, such as millet, sorghum and grain legumes (Oosting et al. 2014). Chemical or biological treatment and mechanical chopping of cereal crop residues also improve the digestibility and palatability. Furthermore, grazing management can play a role both in improving feed intake and in maintaining ecosystem services of rangelands (see Descheemaeker et al. (2009) for an example from the Ethiopian highlands).

\section{Mitigation options}

Ruminants are the main contributor to climate change within agriculture because of the methane produced in the rumen. However, because of the component interactions in mixed crop-livestock systems many mitigation options target the entire farm system, and not specifically the livestock component (Fig. 3). Risk management strategies, such as choosing adapted animal types and breeds, may decrease greenhouse gas emissions rates because of a 
smaller proportion of non-productive animals in the herd. Agroforestry is a diversification option providing improved feed from (often leguminous) trees or shrubs, while at the same time sequestering carbon (Mbow et al. 2014). Better feeding increases production and lowers the greenhouse gas production per $\mathrm{kg}$ of animal produce (Gerber et al. 2013). Most feed management options contribute to sustainable intensification (Fig. 3), which is seen as key strategy for mitigation in African livestock systems (Hristov et al. 2013). Similarly, improving animal husbandry, through, for example, veterinary care, improved breeding, and stall feeding can lead to a lower "herd overhead" and hence less emissions per unit of product (Gerber et al. 2013). The biggest gain in mitigation from smallholder systems could, however, be obtained from reducing the number of animals utilizing a given feed base (Oosting et al. 2014), which is currently difficult due to the multifunctionality of livestock (Fig. 1). Nevertheless, improving the availability of inputs, like mineral fertilizer, or mechanized cultivation and weeding tools to replace animal draught power, would decrease the dependence on animals. This could promote keeping fewer but better fed animals (Oosting et al. 2014), enabling higher animal and herd productivity and lower greenhouse gas emission rates. As mentioned above, rangeland and grazing management can contribute to healthy ecosystem functioning, and with respect to mitigation, lead to carbon sequestration (Thornton and Herrero 2010). Finally, improvements in manure collection, storage and handling can reduce methane and $\mathrm{N}_{2} \mathrm{O}$ losses (Rufino et al. 2006), while at the same time improving soil fertility and crop production, potentially leading to a positive feedback to improved livestock feeding.

\section{Limits and constraints to adaptation and mitigation}

A multitude of solutions are available that can prevent African agriculture to be adversely affected by climate change and can decrease greenhouse gas emissions. However, across the African continent the disappointingly low adoption rates of solutions are a reason for concern (Cooper et al. 2008; Cavatassi et al. 2011). The literature on adoption of agricultural innovations helps to shed light also on the challenges with regard to adaptation and mitigation in mixed farming systems. In general, the adoption potential of a certain option depends on its fit with the agroecological, sociocultural, economic and institutional dimensions of the farmer's context (Ojiem et al. 2006), which includes factors at spatial and organizational levels beyond the farm boundary. In this section, we start with some general constraints and then highlight three specific aspects that play a role at farm level, leading to a call for transformative changes.

\section{Multi-scale constraints}

At the farm level, limited and insecure access to natural, capital and labour resources restrict incentives and opportunities for farmers to invest in or make changes to their farm towards higher agricultural productivity, increased resilience and mitigation of climate change. Vulnerable and disadvantaged groups in society are often more resource constrained, which may explain their limited adaptive capacity (Jones 2012). Beyond the farm, factors at higher spatial and organizational scales, such as poor community organization and malfunctioning extension services, result in poor information flows, knowledge and skills. Motivation may be related also to cultural beliefs that attribute adverse changes in the climate to fate, hence prompting farmers to accept rather than address challenges (Niang et al. 2014). Important institutional constraints at regional and national scales include poor market infrastructure and organization (Cavatassi et al. 2011), coupled with the absence and unaffordable cost of inputs and price uncertainty. Furthermore, the typical communal land tenure system of African rangelands is a disincentive for investments in improved grazing and rangeland management, as individual decisions may be offset by community herd dynamics.

\section{Farm size, risk and livestock multi-functionality}

The effects of new technologies or options are often evaluated at the component level, such as the crop, the field or the animal, where their impact may appear considerable. Yet at the farm level-the level at which households make decisions-the effects on food security, income or livelihoods are often small. In many African regions, small farm sizes prevent investments in improved technologies or practices to be economically viable (Harris and Orr 2014). With continued population growth and further shrinkage of farms (van Vliet et al. 2015), an increasing proportion of the farm population will fall below the food self-sufficiency line. Such farmers are either unable to invest in adaptation and mitigation options, or not motivated to do so because they rely heavily on off-farm activities for their livelihood. The importance of farm size is illustrated in a whole-farm modelling study of mixed systems in Zimbabwe. Masikati et al. (2015) showed that an incremental adaptation package combining improved maize cultivars with forage legumes in the rotation and fertilizer application, led to higher economic returns for larger farms with cattle than for smaller farms. The adaptation package did not affect poverty levels for low- and medium-resource 
endowed farms at all and had only a slight effect for the better-off farms (Fig. 4).

In theory, adaptation and mitigation options result in improved farm performance and less vulnerability. In reality, farmers face a high risk that there will be no response to an input or a change in practice, and a negative return to investment (Fig. 5). On non-responsive soils, this can be due to severe nutrient deficiencies, often related to low soil organic matter content (Vanlauwe et al. 2015). Within and across farms, the spatial heterogeneity in soil fertility is often considerable (Giller et al. 2011). This onfarm variability in conditions and crop responses cannot be captured through on-station trials or crop modelling, but only through conducting numerous on-farm trials (e.g. Bielders and Gérard 2015). Most crop growth models used in climate change impact studies include effects of nitrogen, and sometimes phosphorus dynamics, but do not typically capture other (micro-) nutrients. Also pests and diseases or the poor quality of seeds and other agricultural inputs, which may be responsible for non-responsiveness, are not taken into account in current models. This leads to a potential overestimation of the positive impacts of adaptation and mitigation options. Farmers, however, take this risk into account in their decisions, and this risk acts as a disincentive to invest in inputs or to change farm management practices.

In smallholder mixed farms, the multi-functionality of the herd works as a disincentive to reduce herd sizes (see also "Mixed crop-livestock farming systems and scope of this

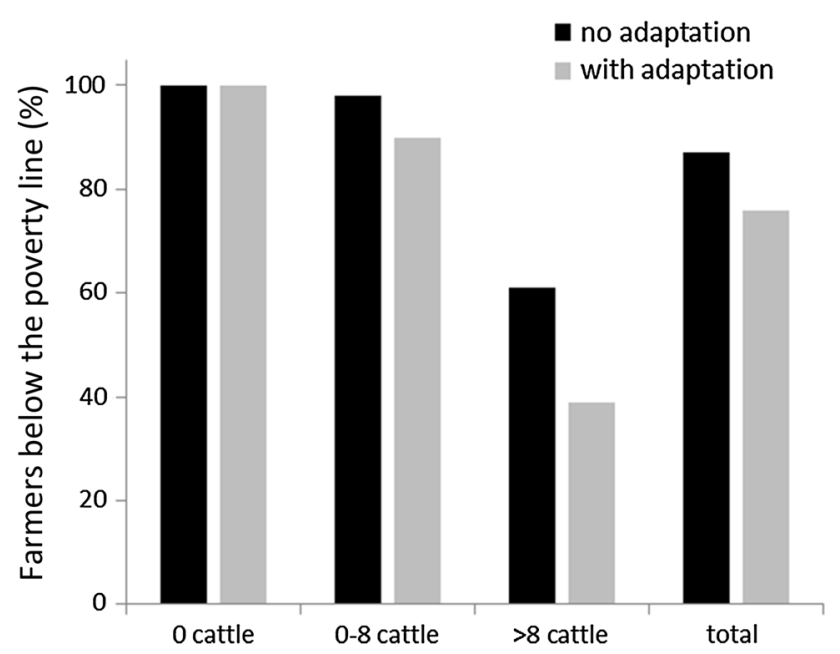

Fig. 4 Poverty levels (\% of farmers below the 1.25 US\$ poverty line) of future systems with and without climate change adaptation for three farm types (based on cattle holding) and the entire population of the semi-arid district of Nkayi in Zimbabwe, based on a multi-model integrated assessment (adapted from Masikati et al. 2015). The adaptation package consisted of an adapted maize variety, rotation with the forage legume crop Mucuna and fertilizer application at $17 \mathrm{~kg} \mathrm{~N} / \mathrm{ha}$ on maize. Details of the methodology, study area and data in Masikati et al. (2015) study" and "Mitigation options" sections), which would be a promising pathway to improve productivity and reduce greenhouse gas emission rates (Oosting et al. 2014). Besides a host of cultural norms, the absence of marketing incentives, insurance and credit facilities is currently preventing the intensification that would enable a shift towards smaller herds (Nielsen and Reenberg 2010). Furthermore, the expected shift to livestock keeping in areas where crop suitability decreases (see "Effects of climate change on mixed crop-livestock systems" section) may counteract efforts towards reducing herd sizes for greenhouse gas mitigation purposes.

\section{Transformative change}

Many of the toughest constraints and barriers to adoption are at stake beyond the farm level and are outside the control of the farmers. Hence, farm-level options for adaptation and mitigation will be effective only if supported by institutions that enable change (Fig. 3). From the above overview, it is clear that the constellation and boundaries of current systems may considerably limit the effect and uptake potential of promising options. Small farm sizes are probably the most important current restriction to improving people's livelihoods and resilience to climate change. The fact that with increasing population densities farm sizes are expected to decrease further puts even more weight on this challenge. Together with high investment risk, poor access to inputs, market dysfunction and land tenure insecurity, it indicates the need for transformative change rather than incremental adaptations (Kates et al. 2012, Porter et al. 2014). Such societal change should include measures to (1) cushion farmers against risk, such as insurance schemes, weather forecasting and early warning systems, (2) build the capacity and skills of farmers and other value chain actors to adopt more diverse systems through, for example, functioning seed systems and extension services, and (3) foster farm investments through credit schemes, land tenure security, and market and value chain development (Fig. 3). In particular, effective insurance schemes could alleviate the need for keeping large livestock herds as a risk management strategy, thus facilitating keeping less and more productive animals (Müller et al. 2011). Despite the ongoing debate on their viability and potential impact (Binswanger-Mkhize 2012), evidence is building up that weather-index insurance systems can benefit smallholders at a meaningful scale (Greatrex et al. 2015).

\section{Prospects}

Farmers, policy-makers, research and development actors need context-specific information on the likely effects of adaptation and mitigation options under current and future 


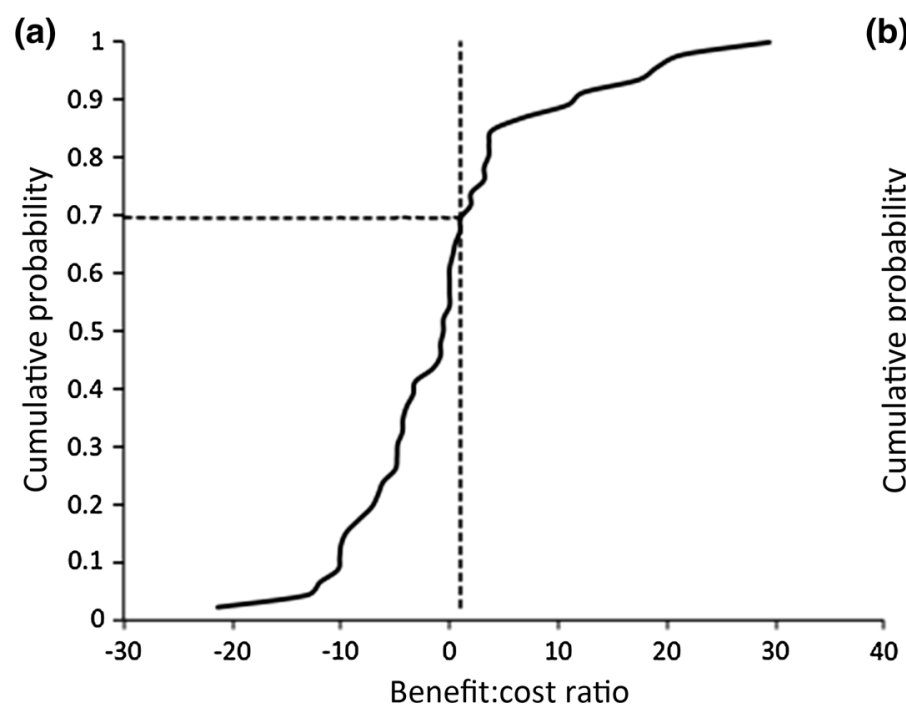

Fig. 5 Cumulative probability distribution of the benefit/cost ratio $\mathbf{a}$ of an improved sorghum hybrid variety and $\mathbf{b}$ of combined mineral and organic fertilizer application (DAP $75 \mathrm{~kg} / \mathrm{ha}+$ compost 9t/ha) on a local sorghum variety in southern Mali. The dashed lines indicate

climate in order to make informed decisions. Similarly to information on climate change impact, this is typically generated through modelling studies and ex ante impact assessments. Current agricultural model capabilities limit the assessment of climate change impacts, in particular with respect to the animal component and the whole-farm level, as well as the range of adaptation and mitigation options that can be investigated. Besides expanding the biophysical modelling capability to more (annual and perennial) crops and livestock species, farm-level assessments need to integrate component information so that changes in the interactions between farm components and the trade-offs associated with farmer decision-making can be investigated (Thornton and Herrero 2015). The other aspect that needs to be addressed is the large heterogeneity in biophysical and socio-economic contexts and farming systems that is typical for Africa (Giller et al. 2011). This results first of all in a large variety of responses to climate change and adaptation and mitigation and secondly in a large range of adoption potentials. Firstly, modelling the effects of climate change, adaptation and mitigation at farm population level, taking farm diversity into account, is a way to unravel the complexity. Secondly, explicitly accounting for the adoption potential through an analysis of costs and benefits and constraints at farm and higher levels helps to make impact assessments more realistic. Detailed household information on resource endowments and agricultural practices can also complement the global analyses of climate change impacts, which have received recent attention (Rosenzweig et al. 2014). The combination of these scientific advances with local and traditional knowledge through

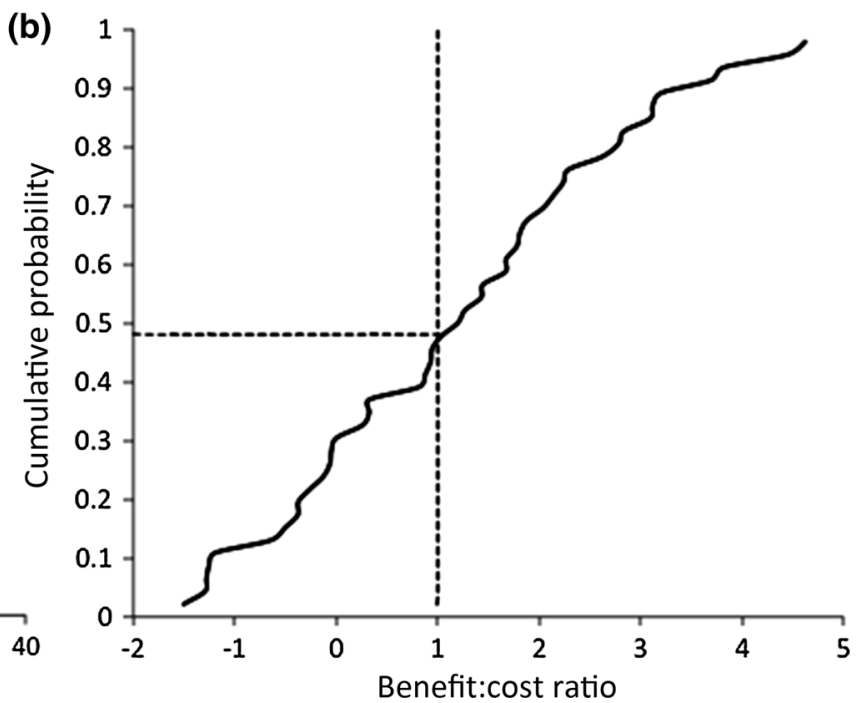

the probability of achieving a benefit/cost ratio equal to one. Data from 20 to 26 on-farm trials in 2013 and 2014, respectively (unpublished data)

participatory processes can enhance the adaptive capacity of local communities (Mapfumo et al. 2013; Traoré et al. 2015). It is increasingly recognized that effects of socioeconomic, institutional and demographic changes will probably outweigh climate change effects, especially in the short term. Hence, there is a need to investigate effects of climate change and adaptation on future systems through scenario analyses (Müller 2013). By considering local dynamics in constraints and opportunities, integrated modelling can be used to inform participatory scenario analyses and support the choice for strategies and interventions in a forward-looking way. This means thinking beyond the current system configuration and boundaries, discussing desired states with stakeholders and exploring how these desired states can be "climatesmart" or "climate-proof".

Acknowledgments We would like to thank the support of DFID for the AgMIP Regional Integrated Assessment project in southern Africa, and of the McKnight Foundation for the project on Pathways to agro-ecological intensification in southern Mali.

Open Access This article is distributed under the terms of the Creative Commons Attribution 4.0 International License (http://crea tivecommons.org/licenses/by/4.0/), which permits unrestricted use, distribution, and reproduction in any medium, provided you give appropriate credit to the original author(s) and the source, provide a link to the Creative Commons license, and indicate if changes were made.

\section{References}

Abeba T, Wiersum KF, Bongers F (2010) Spatial and temporal variation in crop diversity in agroforestry homegardens of 
southern Ethiopia. Agrofor Syst 78:309-322. doi:10.1007/ s10457-009-9246-6

Andrieu N, Descheemaeker K, Sanou T, Chia E (2015) Effects of technical interventions on flexibility of farming systems in Burkina Faso: lessons for the design of innovations in West Africa. Agric Syst 136:125-137. doi:10.1016/j.agsy.2015.02.010

Asseng S, Foster I, Turner NC (2011) The impact of temperature variability on wheat yields. Glob Change Biol 17:997-1012. doi:10.1111/j.1365-2486.2010.02262.x

Bielders CL, Gérard B (2015) Millet response to microdose fertilization in south-western Niger: effect of antecedent fertility management and environmental factors. Field Crops Res 171:165-175. doi:10.1016/j.fcr.2014.10.008

Binswanger-Mkhize HP (2012) Is there too much hype about indexbased agricultural insurance? J Dev Stud 48:187-200. doi:10. 1080/00220388.2011.625411

Campbell BM, Thornton P, Zougmoré R, van Asten P, Lipper L (2014) Sustainable intensification: What is its role in climate smart agriculture? Curr Opin Environ Sustain 8:39-43. doi:10. 1016/j.cosust.2014.07.002

Carter MR, Barrett CB (2006) The economics of poverty traps and persistent poverty: an asset-based approach. J Dev Stud 42:178-199. doi:10.1080/00220380500405261

Cavatassi R, Lipper L, Narloch U (2011) Modern variety adoption and risk management in drought prone areas: insights from the sorghum farmers of eastern Ethiopia. Agric Econ 42:279-292. doi:10.1111/j.1574-0862.2010.00514.x

Claessens L, Antle JM, Stoorvogel JJ, Valdivia RO, Thornton PK, Herrero M (2012) A method for evaluating climate change adaptation strategies for small-scale farmers using survey, experimental and modeled data. Agric Syst 111:85-95. doi:10. 1016/j.agsy.2012.05.003

Cooper PJM, Dimes J, Rao KPC, Shapiro B, Shiferaw B, Twomlow S (2008) Coping better with current climatic variability in the rainfed farming systems of sub-Saharan Africa: An essential first step in adapting to future climate change? Agric Ecosyst Environ 126:24-35. doi:10.1016/j.agee.2008.01.007

Dercon S (2004) Growth and shocks: evidence from rural Ethiopia. J Dev Econ 74:309-329. doi:10.1016/j.jdeveco.2004.01.001

Descheemaeker K, Raes D, Nyssen J, Poesen J, Haile M, Deckers J (2009) Changes in water flows and water productivity upon vegetation regeneration on degraded hillslopes in northern Ethiopia: a water balance modelling exercise. Rangel J 31:237-249. doi:10.1071/RJ09010

Descheemaeker K, Amede T, Haileslassie A, Bossio D (2011) Analysis of gaps and possible interventions for improving water productivity in crop-livestock systems of Ethiopia. Exp Agric 47(S1):21-38. doi:10.1017/S0014479710000797

Ejeta G (2010) African green revolution needn't be a mirage. Science 327:831-832. doi:10.1126/science.1187152

FAO (Food and Agriculture Organization of the United Nations) (2014) FAOSTAT (Database) (Latest update: 07 Mar 2014). http://faostat3.fao.org/home/E. Accessed 12 Apr 2015

Gerber PJ, Hristov AN, Henderson BL, Makkar HPS, Oh J, Lee C, Meinen R, Montes F, Ott T, Firkins J, Rotz A, Dell C, Adesogan AT, Yang WZ, Tricarico JM, Kebreab E, Waghorn G, Dijkstra J, Oosting SJ (2013) Technical options for the mitigation of direct methane and nitrous oxide emissions from livestock: a review. Animal 7:220-234. doi:10.1017/S1751731113000876

Giller KE, Tittonell P, Rufino MC, van Wijk MT, Zingore S, Mapfumo P, Adjei-Nsiah S, Herrero M, Chikowo R, Corbeels M, Rowe EC, Baijukya F, Mwijage A, Smith J, Yeboah E, van der Burg WJ, Sanogo OM, Misiko M, de Ridder N, Karanja S, Kaizzi C, K'ungu J, Mwale M, Nwaga D, Pacini C, Vanlauwe B (2011) Communicating complexity: integrated assessment of trade-offs concerning soil fertility management within African farming systems to support innovation and development. Agric Syst 104:191-203. doi:10.1016/j.agsy.2010.07.002

Gonzalez P, Neilson RP, Lenihan JM, Drapek RJ (2010) Global patterns in the vulnerability of ecosystems to vegetation shifts due to climate change. Glob Ecol Biogeogr 19(6):755-768. doi:10.1111/j.1466-8238.2010.00558.x

Greatrex H, Hansen JW, Garvin S, Diro R, Blakeley S, Le Guen M, Rao KN, Osgood DE (2015) Scaling up index insurance for smallholder farmers: recent evidence and insights. CCAFS Report No. 14 Copenhagen: CGIAR Research Program on Climate Change, Agriculture and Food Security (CCAFS)

Harris D, Orr A (2014) Is rainfed agriculture really a pathway from poverty? Agric Syst 123:84-96. doi:10.1016/j.agsy.2013.09.005

Hristov AN, Ott T, Tricarico J, Rotz A, Waghorn G, Adesogan AT, Dijkstra J, Montes F, Oh J, Kebreab E, Oosting SJ, Gerber PJ, Henderson BL, Makkar HPS, Firkins JL (2013) Mitigation of methane and nitrous oxide emissions from animal operations: III. A review of animal management mitigation options. J Anim Sci 91:5095-5113. doi:10.2527/jas.2013-6585

Jayne TS, Zulu B, Nijhoff JJ (2006) Stabilizing food markets in eastern and southern Africa. Food Policy 31(4):328-341. doi:10. 1016/j.foodpol.2006.03.008

Jones L (2012) Social barriers to adaptation: exploring implications and identifying options for adaptation policy across the SADC Region. In: Masters L, Duff L (eds) Overcoming barriers to climate change adaptation implementation in southern Africa. Africa Institute of South Africa, Pretoria, pp 41-60

Jones PG, Thornton PK (2009) Croppers to livestock keepers: livelihood transitions to 2050 in Africa due to climate change. Environ Sci Policy 12:427-437. doi:10.1016/j.envsci.2008.08. 006

Kamanga BCG, Waddington SR, Whitbread AM, Almekinders CJM, Giller KE (2014) Improving the efficiency of use of small amounts of nitrogen and phosphorus fertiliser on 30 smallholder maize in central Malawi. Exp Agric 50:229-249. doi:10.1017/ S0014479713000513

Kates RW, Travis WR, Wilbanks TJ (2012) Transformational adaptation when incremental adaptations to climate change are insufficient. Proc Natl Acad Sci 109:7156-7161. doi:10.1073/ pnas.1115521109

Laube W, Schraven B, Awo M (2012) Smallholder adaptation to climate change: dynamics and limits in Northern Ghana. Clim Change 111(3):753-774. doi:10.1007/s10584-011-0199-1

Lipper L, Thornton P, Campbell BM, Baedeker T, Braimoh A, Bwalya M, Caron P, Cattaneo A, Garrity D, Henry K, Hottle R, Jackson L, Jarvis A, Kossam F, Mann W, McCarthy N, Meybeck A, Neufeldt H, Remington T, Sen PT, Sessa R, Shula R, Tibu A, Torquebiau EF (2014) Climate-smart agriculture for food security. Nat Clim Change 4:1068-1072. doi:10.1038/ nclimate 2437

Liu J, Fritz S, van Wesenbeeck CFA, Fuchs M, You L, Obersteiner M, Yang H (2008) A spatially explicit assessment of current and future hotspots of hunger in sub-Saharan Africa in the context of global change. Glob Planet Change 64(3-4):222-235. doi:10. 1016/j.gloplacha.2008.09.007

Mapfumo P, Adjei-Nsiah S, Mtambanengwe F, Chikowo R, Giller KE (2013) Participatory action research (PAR) as an entry point for supporting climate change adaptation by smallholder farmers in Africa. Environ Dev 5:6-22. doi:10.1016/j.envdev.2012.11.001

Marenya PP, Barrett CB (2009) Soil quality and fertilizer use rates among smallholder farmers in western Kenya. Agric Econ 40:561-572. doi:10.1111/j.1574-0862.2009.00398.x

Masikati P, Homann-Kee Tui S, Descheemaeker K, Crespo O, Walker S, Lennard CJ, Claessens L, Gama AC, Famba S, van Rooyen AF, Valdivia RO (2015) Crop-livestock intensification in the face of climate change: exploring opportunities to reduce risk 
and increase resilience in southern Africa by using an integrated multi-modeling approach. In: Rosenzweig C, Hillel D (eds) Handbook of climate change and agroecosystems: the Agricultural Model Intercomparison and Improvement Project (AgMIP) Integrated Crop and Economic Assessments. Joint Publication with American Society of Agronomy, Crop Science Society of America, and Soil Science Society of America, Imperial College Press, London, pp 159-200. doi:10.1142/9781783265640_0017

Mbow C, Van Noordwijk M, Luedeling E, Neufeldt H, Minang PA, Kowero G (2014) Agroforestry solutions to address food security and climate change challenges in Africa. Curr Opin Environ Sustain 6:61-67. doi:10.1016/j.cosust.2013.10.014

Mekonnen S, Descheemaeker K, Tolera A, Amede T (2011) Livestock water productivity in a water stressed environment in northern Ethiopia. Exp Agric 47(S1):85-98. doi:10.1017/ S0014479710000852

Milgroom J, Giller KE (2013) Courting the rain: rethinking seasonality and adaptation to recurrent drought in semi-arid southern Africa. Agric Syst 118:91-104. doi:10.1016/j.agsy.2013.03.002

Molden D (2007) Water for food, water for life: a comprehensive assessment of water management in agriculture. Earthscan, London and International Water Management Institute, Colombo

Moll HAJ (2005) Costs and benefits of livestock systems and the role of market and nonmarket relationships. Agric Econ 32:181-193. doi:10.1111/j.0169-5150.2005.00210.x

Morton JF (2007) The impact of climate change on smallholder and subsistence agriculture. Proc Natl Acad Sci 10:19680-19685. doi:10.1073/pnas.0701855104

Moser SC, Ekstrom JA (2010) A framework to diagnose barriers to climate change adaptation. Proc Natl Acad Sci USA 107:22026-22031. doi:10.1073/pnas.1007887107

Müller C (2013) African lessons on climate change risks for agriculture. Annu Rev Nutr 33:395-411. doi:10.1146/annurevnutr-071812-161121

Müller B, Quaas MF, Frank K, Baumgärtner S (2011) Pitfalls and potential of institutional change: rain-index insurance and the sustainability of rangeland management. Ecol Econ 70:2137-2144. doi:10.1016/j.ecolecon.2011.06.011

Niang I, Ruppel OC, Abdrabo MA, Essel A, Lennard C, Padgham J, Urquhart P (2014) Africa. In: Barros VR et al (eds) Climate Change 2014: impacts, adaptation, and vulnerability. Part B: regional aspects. Contribution of Working Group II to the Fifth Assessment Report of the Intergovernmental Panel on Climate Change. Cambridge University Press, Cambridge and New York, NY, pp 1199-1265

Nielsen JØ, Reenberg A (2010) Cultural barriers to climate change adaptation: a case study from Northern Burkina Faso. Glob Environ Change 20(1):142-152. doi:10.1016/j.gloenvcha.2009. 10.002

Nin-Pratt A, Johnson M, Yu B (2012) Improved performance of agriculture in Africa South of the Sahara: taking off or bouncing back. IFPRI Discussion Paper 01224. International Food Policy Research Institute (IFPRI), Washington, DC

Ojiem JO, de Ridder N, Vanlauwe B, Giller KE (2006) Socioecological niche: a conceptual framework for integration of legumes in smallholder farming systems. Int J Agric Sustain 4:79-93. doi:10.1080/14735903.2006.9686011

Oosting SJ, Udo HMJ, Viets TC (2014) Development of livestock production in the tropics: farm and farmers' perspectives. Animal 8:1238-1248. doi:10.1017/S1751731114000548

Porter JR, Semenov MA (2005) Crop responses to climatic variation. Philos Trans R Soc B Biol Sci 360:2021-2035. doi:10.1098/rstb. 2005.1752

Porter JR, Xie L, Challinor AJ, Cochrane K, Howden SM, Iqbal MM, Lobell DB, Travasso MI (2014) Food security and food production systems. In: Field $\mathrm{CB}$ et al (eds) Climate change
2014: impacts, adaptation, and vulnerability. Part A: global and sectoral aspects. Contribution of Working Group II to the Fifth Assessment Report of the Intergovernmental Panel on Climate Change. Cambridge University Press, Cambridge and New York, NY, pp 485-533

Rickards L, Howden SM (2012) Transformational adaptation: agriculture and climate change. Crop Pasture Sci 63:240-250. doi:10.1071/CP11172

Rosenzweig C, Elliott J, Deryng D, Ruane AC, Müller C, Arneth A, Boote KJ, Folberth C, Glotter M, Khabarov N (2014) Assessing agricultural risks of climate change in the 21 st century in a global gridded crop model intercomparison. Proc Natl Acad Sci 111:3268-3273. doi:10.1073/pnas.1222463110

Rufino MC, Rowe EC, Delve RJ, Giller KE (2006) Nitrogen cycling efficiencies through resource-poor African crop-livestock systems. Agric Ecosyst Environ 112:261-282. doi:10.1016/j.agee. 2005.08.028

Rurinda J, Mapfumo P, van Wijk MT, Mtambanengwe F, Rufino MC, Chikowo R, Giller KE (2014) Sources of vulnerability to a variable and changing climate among smallholder households in Zimbabwe: a participatory analysis. Clim Risk Manag 3:65-78. doi:10.1016/j.crm.2014.05.004

Rurinda J, van Wijk MT, Mapfumo P, Descheemaeker K, Supit I, Giller KE (2015) Climate change and maize yield in southern Africa: What can farm management do? Glob Change Biol 21:4588-4601. doi:10.1111/gcb.13061

Schlenker W, Lobell DB (2010) Robust negative impacts of climate change on African agriculture. Environ Res Lett 5:014010. doi: $10.1088 / 1748-9326 / 5 / 1 / 014010$

Seebauer M (2014) Whole farm quantification of GHG emissions within smallholder farms in developing countries. Environ Res Lett 9:035006. doi:10.1088/1748-9326/9/3/035006

Smaling EMA, Nandwa S, Janssen BH (1997) Soil fertility in Africa is at stake! In: Buresh RJ et al (eds) Recapitalization of soil nutrient capital in sub-Saharan Africa. ASSA, CSSA, SSSA, Madison, Wisconsin, pp 47-61

Sultan B, Roudier P, Quirion P, Alhassane A, Muller B, Dingkuhn M, Ciais P, Guimberteau M, Traoré S, Baron C (2013) Assessing climate change impacts on sorghum and millet yields in the Sudanian and Sahelian savannas of West Africa. Environ Res Lett 8:014040. doi:10.1088/1748-9326/8/1/014040

Tarawali S, Herrero M, Descheemaeker K, Grings E, Blümmel M (2011) Pathways for sustainable development of mixed crop livestock systems: taking a livestock and pro-poor approach. Livest Sci 139:11-21. doi:10.1016/j.livsci.2011.03.003

Thornton PK, Herrero M (2010) Potential for reduced methane and carbon dioxide emissions from livestock and pasture management in the tropics. Proc Natl Acad Sci 107:19667-19672. doi:10.1073/pnas.0912890107

Thornton PK, Herrero M (2014) Climate change adaptation in mixed crop-livestock systems in developing countries. Glob Food Secur 3:99-107. doi:10.1016/j.gfs.2014.02.002

Thornton PK, Herrero M (2015) Adapting to climate change in the mixed crop and livestock farming systems in sub-Saharan Africa. Nat Clim Change 5:830-836. doi:10.1038/nclimate2754

Thornton PK, Kruska RL, Henninger N, Kristjanson PM, Reid RS, Atieno F, Odero A, Ndegwa T (2002) Mapping poverty and livestock in the developing world. ILRI (International Livestock Research Institute), Nairobi

Thornton PK, van de Steeg J, Notenbaert A, Herrero M (2009) The impacts of climate change on livestock and livestock systems in developing countries: a review of what we know and what we need to know. Agric Syst 101:113-127. doi:10.1016/j.agsy.2009. 05.002

Thornton PK, Jones PG, Alagarswamy G, Andresen J, Herrero M (2010) Adapting to climate change: agricultural system and 
household impacts in East Africa. Agric Syst 103:73-82. doi:10. 1016/j.agsy.2009.09.003

Tingem M, Rivington M (2009) Adaptation for crop agriculture to climate change in Cameroon: turning on the heat. Mitig Adapt Strateg Glob Change 14:153-168. doi:10.1007/s11027-0089156-3

Toulmin C (1994) Tracking through drought: options for destocking and restocking. In: Scoones I (ed) Living with uncertainty. New directions in pastoral development in Africa. International Institute for Environment and Development, London, pp 95-115

Traoré B, Corbeels M, van Wijk MT, Rufino MC, Giller KE (2013) Effects of climate variability and climate change on crop production in southern Mali. Eur J Agron 49:115-125. doi:10. 1016/j.eja.2013.04.004

Traoré B, van Wijk MT, Descheemaeker K, Corbeels M, Rufino MC, Giller KE (2014) Evaluation of climate adaptation options for Sudano-Sahelian cropping systems. Field Crops Res 156:63-75. doi:10.1016/j.fcr.2013.10.014

Traoré B, van Wijk MT, Descheemaeker K, Corbeels M, Rufino MC, Giller KE (2015) Climate variability and change in southern Mali: learning from farmer perceptions and on-farm trials. Exp Agric. doi:10.1017/S0014479714000507 (in press)

Turner MD, Ayantunde AA, Patterson KP, Patterson ED (2011) Livelihood transitions and the changing nature of farmer-herder conflict in Sahelian West Africa. J Dev Stud 47:183-206. doi:10. 1080/00220381003599352

Valbuena D, Homann-Kee Tui S, Erenstein O, Teufel N, Duncan A, Abdoulaye T, Swain B, Mekonnen K, Germaine I, Gérard B
(2015) Identifying determinants, pressures and trade-offs of crop residue use in mixed smallholder farms in sub-Saharan Africa and South Asia. Agric Syst 134:107-118. doi:10.1016/j.agsy. 2014.05.013

Van Ittersum MK, Cassman KG, Grassini P, Wolf J, Tittonell P, Hochman Z (2013) Yield gap analysis with local to global relevance—a review. Field Crops Res 143:4-17. doi:10.1016/j. fcr.2012.09.009

van Vliet JA, Schut AGT, Reidsma P, Descheemaeker K, Slingerland M, van de Ven GWJ, Giller KE (2015) De-mystifying family farming: features, diversity and trends across the globe. Glob Food Secur 5:11-18. doi:10.1016/j.gfs.2015.03.001

Vanlauwe B, Descheemaeker K, Giller KE, Huising J, Merckx R, Nziguheba G, Wendt J, Zingore S (2015) Integrated soil fertility management in sub-Saharan Africa: unravelling local adaptation. Soil 1:491-508. doi:10.5194/soil-1-491-2015

Vetter S (2005) Rangelands at equilibrium and non-equilibrium: recent developments in the debate. J Arid Environ 62:321-341. doi:10.1016/j.jaridenv.2004.11.015

Waha K, Müller C, Bondeau A, Dietrich JP, Kurukulasuriya P, Heinke J, Lotze-Campen H (2013) Adaptation to climate change through the choice of cropping system and sowing date in subSaharan Africa. Glob Environ Change 23:130-143. doi:10.1016/ j.gloenvcha.2012.11.001

Wood SA, Karp DS, DeClerck F, Kremen C, Naeem S, Palm CA (2015) Functional traits in agriculture: agrobiodiversity and ecosystem services. Trends Ecol Evol 30:531-539. doi:10.1016/ j.tree.2015.06.013 